\title{
Precarity and Elemental \\ Difference: On Butler's \\ Re-writing of Irigarayan \\ Difference
}

\author{
Emily Anne Parker
}

\begin{abstract}
It is widely accepted that Judith Butler's work represents a fundamental departure from that of Luce Irigaray. However, in a $200 \mathrm{I}$ essay, Butler suggests that Irigaray's work plays a formative role in her own, and that the problematization of the biological and cultural distinction that Irigaray's notion of sexual difference accomplishes must be rethought and multiplied rather than simply rejected. In this essay, I place the notion of precarity in the work of Butler alongside that of sexual difference in Irigaray, to show how together they seek to address violence to certain bodies through an approach that is at once ecological and political. I show that Butler's concept of precarity has deep, largely unappreciated, roots in the work of Irigaray. Butler explores precarity as bodily multiplicity in ways that pluralize Irigaray's own ethics and politics of difference. Butler is, in other words, rewriting sexual difference as precarity.
\end{abstract}

\section{Keywords}

difference, elemental, precarity, Anthropocene, the body 


\section{Introduction: Reading Butler and Irigaray in the Anthropocene}

Judith Butler has recently suggested that exhortations to "even the most powerless to take responsibility for their own lives without depending on anyone or anything else" constitute "a war on the idea of interdependency,"1 a futile effort to deny the collective and plural qualities of all material life. Illness, injury, and natural disaster are treated as accidental aspects of life for which there should be no collective concern. Butler offers instead an ethics of bodily life, one which is indistinguishable from "a sustaining and sustainable world." 2 She develops the figure of precarity to refer both to the specific modes of violence done to human life deemed non-normative and to the necessary availability or relationality to others that makes such violence possible in the first place. $^{3}$ The figure of precarity is a way of tracing political violence, which is all too often severed from the ecological to which it is irrevocably tied, back to its characteristic violation of material life: it traces the unjust exposure of some bodies back to the denial of exposure or openness as a feature of bodily life per se, even if different bodies encounter it in irreducibly different ways. Affirmation of interdependence, Butler suggests, means appreciating this larger political-ecological web of relations, the place of the political as and within a larger ecological relationality. ${ }^{4}$

In what follows, I place Butler alongside Luce Irigaray, to show how together they seek to address the violence against certain bodies through an approach that is at once ecological and political. Butler's concept of precarity, I will argue, has deep, largely unappreciated, roots in the work of Luce Irigaray; Butler explores precarity as bodily multiplicity in ways that pluralize Irigaray's own ethics and politics of difference. ${ }^{5}$ Butler is, in other words, rewriting sexual difference as precarity.

Like Butler, Irigaray objects to the denial of interdependence that characterizes the discourse of self-responsible individuals. Unlike Butler, she ties this explicitly to the denial of the heterogeneity or nongeneric quality of human bodies in their dependence on things of all sorts: micro-organisms, air, water, bacteria, strangers, familiars. ${ }^{6}$ In other words, for Irigaray, to truly acknowledge interdependence and plurality is to admit the heterogeneity between and within the bodies in question. Bodies have different abilities; they do different things. They have irreducibly different needs that must be collectively secured, even if current conceptions of equality tend to presume sameness as a feature of independence. Irigaray also suggests that interdependence is not a per se good: ${ }^{7}$ she affirms instead forms of mutual reliance that not only cultivate an appreciation of dependence but also pursue modes of interdependence in which all parties, whose physicalities are not identical 
or interchangeable, thrive. ${ }^{8}$ The key feature here is acknowledgment of difference, where sexual difference ${ }^{9}$ dimorphically understood (infamously) serves for her as the most basic and most crucial mode of difference. Irigaray is therefore interested not only in the valuation of interdependence but also in articulating arrangements of dependence that nourish mutually distinct participants, both politically and ecologically speaking. In her view, what is called for is an elemental philosophy of difference that takes dependence and heterogeneity to be synonymous with bodies, something bodies do as vibrant matter, ${ }^{10}$ and not only something that human bodies consciously or unconsciously create as meaning, then criminalize, or securitize in a realm somehow distinct from the ecological.

Thus, for both Butler ${ }^{11}$ and Irigaray, interdependence is a feature of material life per se and of the plurality of bodies within it. As I will show, though Butler and Irigaray articulate different versions of bodily plurality, they share an approach that knits together the "political" with the "ecological." Together they also shed light on contemporary discussions of the “Anthropocene." In 2008, The International Commission on Stratigraphy created an Anthropocene Working Group tasked with deciding whether there should be an alteration to the Geological Time Scale, one that acknowledges what Simon Lewis and Mark Maslin describe as "the magnitude, variety and longevity of human-induced changes, including land surface transformation and changing . . composition of the atmosphere."12 Lewis and Maslin point out that it was the "arrival of Europeans in the Caribbean in 1492, and subsequent annexing of the Americas, [which] led to the largest human population replacement in 13,000 years, the first global trade networks linking Europe, China, Africa and the Americas, and the resultant mixing of previously separate" humans, other animals, plants, bacteria. This Columbian Exchange, as it is called, entailed, among other things, the "globalization of human foodstuffs." 13

The New World crops maize/corn, potatoes and the tropical staple manioc/ cassava were subsequently grown across Europe, Asia and Africa. Meanwhile Old World crops such as sugarcane and wheat were planted in the New World. The cross-continental movement of dozens of other food species (such as the common bean, to the New World), domesticated animals (such as the horse, cow, goat and pig, all to the Americas) and human commensals (the black rat, to the Americas), plus accidental transfers (many earth worms, to North America; American mink to Europe) contributed to a swift, ongoing, radical reorganization of life on Earth without geological precedent. ${ }^{14}$

We see that the Columbian Exchange, far from drawing attention away from the political violence of this period, highlights the violence of colonization. 
Ecological and political violence proceeded together: colonization initiated an unprecedented degree of global homogenization of matter.

Irigaray acknowledges this identity of the political and the ecological when she writes, "Ecology is very fashionable nowadays. However, just as the Western man pretended to dominate nature, to subject it to a culture presumed to be of higher value in relation to nature, today he intends to care for nature." 15 For Irigaray, "Western man" thinks of itself in generic terms; we could say that the concept of the Anthropocene is Western man writ large. ${ }^{16}$ It is a morphology ${ }^{17}$ in which humanity is now to be conceived as a force of nature but yet still in a position of domination. Irigaray helps us to appreciate that in the figure of the Anthropocene, life is still something "outside ourselves," especially insofar as this "our" is expressed as an amorphous block. Irigaray would agree with those who worry about the tendency to speak strictly in terms of cultural dynamics and to conceive of agency in exclusively "human" terms, but her critical focus is upon the generic and abodied quality of the anthropos of the "Anthropocene."

The concept of the Anthropocene itself contains a clue to how we have gotten to this point: "the geologically unprecedented homo-geni-zation of Earth's biota"18 is a morphology of forced homogenization of cultures and an over-identification that takes from others as if they were oneself. It is, in other words, the denial of a difference which nevertheless remains. "Anthropocene," then, is a tellingly homogenizing concept, a concept pitted against "cultivating a living belonging" in difference in Irigaray's sense. To conceive of human life in the generic is to conceive of it as a-bodily, as without location and therefore without language or culture, and it is in this way that the notion Anthropocene reflects the violent "Exchange" with which Lewis and Maslin argue it is synonymous. But to be or rather become a body is never generic or universal. There is in fact no "the body," no generic way to be or become human. In order to begin to think in ways appropriate to earth and to the life and death, the lives and deaths, of that earth, it is necessary to develop concepts for a collective but heterogeneous human life, for a philosophy of difference that exceeds dualities as well as homogeneity. For a philosophy of difference, to paraphrase Aimé Césaire, which is made to the measure of earth. ${ }^{19}$ We have participated, in a kind of violent sync between humans, other animals, and plants, the acceleration of extinctions, amplifying of weather patterns, and increase in the acidity and level of the oceans. These are the intense and ongoing changes that have provoked the crisis of geological conceptualization and the homogenizing term Anthropocene. What is happening is simultaneously an ecological and political crisis, one that calls on us to question precisely this distinction. A new set of concepts is necessary by 
which we can understand ourselves as earth, in which ecology and politics are not treated as two separate spheres. ${ }^{20}$

Butler's concept of precarity offers just such a way of thinking about politics, or modes of cohabitation as she puts it, as an ecological layer governed as well by other relationships. Though precarity is frequently taken to provide a universal basis for a new humanism, ${ }^{21}$ she herself describes it as "another way of imagining community, one in which we are alike only in having this condition separately and so having in common a condition that cannot be thought without difference." 22 And this condition for Butler is both "political" and a negotiation of earth. What Butler means by difference here I read as an interpretation of Luce Irigaray's ethics of sexual difference. Indeed, she says explicitly that she does not wish to do away with the concept of sexual difference, so much as rethink it because it offers a "site where a question concerning the relation of the biological to the cultural is posed and reposed." 23 Despite this, Butler's work is widely regarded as a rejection of the philosophy of sexual difference in Irigaray. Irigaray or Butler. ${ }^{24}$ In what follows, I instead argue that while Butler's concept of precariousness helpfully does break with Irigaray's exclusive interest in and often dualistic interpretation of sexual difference, precarity offers a philosophy of difference that seems to learn much from Irigaray.

\section{Sexual Difference, Re-articulated as Precarity}

In "The End of Sexual Difference?" Butler writes that "sexual difference has psychic, somatic, and social dimensions that are never quite collapsible into one another but are not for that reason ultimately distinct. Does sexual difference vacillate there, as a vacillating border, demanding a rearticulation of those terms without any sense of finality?" ${ }^{25}$ Yes, the somatic, the psychic, the social: doesn't what Butler calls "phobic violence against bodies"26 require a rethinking of these concepts, prior to their splintering, to get around the dispersal that results in these seemingly distinguishable spheres: psychic, somatic, social? Sexual difference, Butler suggests, might allow for an invention of new concepts to obviate these distinctions. ${ }^{27}$

To these terms - psychic, somatic, social — Irigaray would I think add two more. Ecological and political: after all, for Irigaray it is the case that "sexual difference vacillate[s] there . . demanding a rearticulation of those terms." 28 For Irigaray the ecological and the political are not two separate spheres which must be instructed toward meeting. Affirming sexual difference, that there is no human body as such, as a precondition of any possible morphology, Irigaray explains, would constitute a conceptual and practical revolution. She writes in An Ethics of Sexual Difference: "Man has been the subject 
of discourse, whether in theory, morality or politics. And the gender of God, the guardian of every subject and every discourse, is always masculine and paternal, in the West." 29 In Sexes and Genealogies she writes, "Man gives his own gender to the universe as he intends to give his name to his children and his possessions. Everything man considers of value has to be of his gender." 30 Man here is not a value-free description; it is a morphology, characterizing the relations among bodies, which cater to a subset of bodies. But human bodies are neither generic nor are they generic as this one mode of bodiment ${ }^{31}$ would have it, a primary characteristic of which is the denial of the value of bodiment itself and those bodies made to represent it.

We are not the same body, Irigaray is saying, nor are we the same as bodies. And this paradoxically follows from a cosmic belonging: sexual difference is a reminder that we are earth; in addition to the starry skys above and the chestnut tree below we are also the matter that we seek unendingly and inadequately to capture in word and image. As this reminder, sexual difference might "act as a brake upon and a store of resistance against a formalization that threatens life" 32 in its denial of the power of earth, including but not limited to the earth that we ourselves are. The genealogy of the white Western husband (and concomitantly the white Western mother-who-must-be-hiswife) is an attempt to cover over the fecundity and multiplicity of nature, a processual and becoming nature, again, that we ourselves are. Paternal genealogies are a "failure of respect for nature. A new notion or concept of nature is set up, which takes the place of earth's fertility, abandons its religious quality, its link to the divinity of women." 33 Sexual difference could be, if affirmed, an indication of ourselves as a necessarily heterogeneous earth.

The lasting significance of Irigaray's work, I want to suggest, is not so much the recognition of women as the affirmation of bodily singularity or non-identity. "Polis" currently carries the connotations of its birth in ancient Greece in which a very, very few bodies constituted the proper space of contestation. ${ }^{34}$ For Irigaray, this polis just $i$ s the evaporation of the distinctions and asymmetries between one man and another man for the purposes of delimited discourse. ${ }^{35}$ Differential violence against bodies denied by this polis is not only symptomatic of it. It is also an indication of the very fragility of the polis, which works in concert with a multitude of earthly powers on behalf of the short-term interests of certain humans and to the detriment of those human and more-than-human bodies it denies, as for example in the days following Hurricane Katrina's landfall "when," as Spike Lee puts it, "the levees broke." ${ }^{36}$ Elemental difference, in a culture built upon its denial, is that against which a polis conceived homogeneously, and therefore necessarily in an entirely abodily manner, must defend itself in the Anthropocene. ${ }^{37}$ 
One implication of Irigaray's concept of sexual difference is that the political is ecological, the somatic is social. And yet in spite of this, Irigaray often writes as if bodies must and can only be deemed in a biomedical register of male or female, as if the dangers of this polis have only to do with a supposedly one-dimensional process of sexuation which results in two sexes. She adopts, quite surprisingly, the discourse of bodies of Western cultures, the biomedical, in an understanding of what does and doesn't "fail" to be Western man. This has rightfully kept many from taking seriously Irigaray's philosophy of difference. ${ }^{38}$

For that reason I will refer to my own interest in difference in Irigaray as an interest in elemental difference, a difference that is simultaneously "ecological" and "political," of earth and therefore subject to the dynamics among bodies of all sorts. I take this to include but not be limited to what Irigaray names the sexual or sexuate. ${ }^{39}$ The very gesture to "man" in the above passages obscures the fact that it is a very specific set of humans being invoked: that of white hetero people, of bodies free of physical and/or cognitive disability and/or mood disorders, of bodies which identify with the gender they have been identified with by others from birth. It is also referring to that specific culture for which paternity governs genealogy. But couldn't we also ask: what is the role of histories of colonization in the securing of this specific mode of "masculinity" and the concomitant criminalizing or otherwise rejecting of what Jack Halberstam has called minority masculinities? What is the role of morphologies of ability in the securing of relations among those recognized from birth as women? What is the role of race and gender and ability understood as mutually developing threads in the establishing of debtor-creditor relations among those who believe themselves and are believed to be men? Such questions must be among those regarding the force of all things, windstorms, lead, calcium, electricity, in order to inquire into the crucial and multifaceted dynamics that are congenial to a world in which human commitments to climate change and to the task of colluding with earthly powers can deepen and intensify. ${ }^{40}$ Irigaray does not ask these questions, even if her work guides me to ask them. It is necessary to ask such questions, to explore dimensions of elemental life (what I am naming the political-ecological) in ways that do not re-create the obscurity or legal marginalization of those who suffer from the morphological dynamics of, for example, class, race, gender, disability, sexuality, nationality simultaneously. ${ }^{41}$

It was in response to the drawbacks of Irigaray's philosophy of sexual difference that Butler asked, "Why can't the framework for sexual difference itself move beyond binarity into multiplicity?"42 Indeed, Butler seems to be proposing in the concept of precariousness and precarity ${ }^{43}$ another way of affirming sexual difference, which I want to expand into an exploration of 
elemental difference. Butler may herself be skeptical of such an effort, a point I take up in the section on what I call their "two philosophies of difference" below. But what is crucial is that Butler leaves behind Irigaray's myopic however radical concern for a very few bodies to ask how relations among necessarily variable bodies become central to the life of each one. In other words, I read Butler as suggesting that Irigaray's concern for difference might become a concern for morphologies ${ }^{44}$ or concepts that enable a thousand sensate democracies ${ }^{45}$ and sensate oppositions to war, ${ }^{46}$ within a wider vibrant world composed of bodies that inevitably fail to be copies of each other. Butler resists the dimorphism of Irigaray's sexual difference, ${ }^{47}$ but she also asks how a philosophy of difference might function without relying upon gender dimorphism or upon the presupposed centrality of gendering in polis life. My claim is that Irigaray's rather contained concern for what I am calling elemental difference, the singularity necessary to bodiment, holds a promise that Irigaray herself does not explore, a promise that Butler is beginning to open up as precarity.

Although Precarious Life (2004), Frames of War (2009), and Notes toward a Performative Theory of Assembly (2015) do not explicitly present precarity as an interpretation of sexual difference, the term can be read as an impious interpretation of it. Butler is a rogue Irigarayan. With this "new bodily ontology" 48 or morphology that cannot be thought without difference, ${ }^{49}$ Butler eschews both Irigaray's exclusive attention to dimorphous sexuation and rightly cuts against its synecdochical pride of place in the Anthropocene.

In "Violence, Mourning, Politics" (later to become the second chapter of Precarious Life), Butler argues not only that there are hierarchies of grievability, but also hierarchies of things to be grieved: those whose lives are the most beset with violence are the lives least likely to be publicly grieved. This hierarchical distribution of violence, an exacerbation of precarity for some, is due to the denial of precarity of all. Such hierarchies are produced through the denial of what she calls (in Notes toward a Peformative Theory of Assembly) precarity, a characteristic feature of what it is to be a body and a feature that, if denied, is used to create a differential distribution of dependence as an assault on such bodies and not others. Although Precarious Life is a book about mourning, what is crucial for Butler is not mourning so much as the fact that it demonstrates the "disposition of ourselves outside ourselves." ${ }^{50}$ Losing someone or almost losing someone means getting a queasy sensation, a gut response, that indicates that you're losing a part of yourself. Mourning is the sensation of some part of myself coming unhinged, precisely because it was not composed of myself, my body, my life to begin with. Butler writes, 
Let's face it, we're undone by each other. ... This seems so clearly the case with grief, but it can be so only because it was already the case with desire ... despite one's best efforts one is undone, ... by the touch, by the scent, by the feel, by the prospect of the touch, by the memory of the feel. ${ }^{51}$

Precarity is this necessity of being constituted by the bodily lives of others. ${ }^{52}$ Each of us are always "as bodies, outside ourselves and for another." ${ }^{3}$ Self-understanding is predicated upon these relations: having been named by a caregiver or caregivers, having been instructed in gendering-racializing-classifying-otherwisehierarchizing norms by one's community, having seen in commercials, cartoons, video games, movies the meanings of one's body, having seen what this body should do, think, or feel. Having been, having seen: it is not for Butler that we are incapable of developing a concept of ourselves for ourselves, of our own bodies. But such concepts are always going to be predicated upon these prior morphologies that have emanated as the morphologies of other bodies. Becoming a body means becoming as a body inescapably held in the sensations of others, who I am not. As she will put it later, "The body is constituted through perspectives it cannot inhabit." ${ }^{4}$ Why can a body not inhabit the perspectives of others? Is this simply because a body is not other bodies, or might there be features of a life that are simply not translatable to all others?

What's crucial, on my reading, is that for Butler bodies can never be identical or neutral with respect to prevailing morphologies. When she writes that precarity is "another way of imagining community, one in which we are alike only in having this condition separately and so having in common a condition that cannot be thought without difference, $"{ }^{55}$ she is at the very least saying, in a way that Irigaray would endorse, that bodies are not identical. Precarity is relationality, which is by definition an assertion that we are not each other. We are not identical bodies. In fact interdependence would seem to be a strange word choice given that for Butler herself, affects are neither ownable nor recognizable. ${ }^{56}$ As affect, mourning demonstrates that "one's body is never fully one's own, bounded and self-referential." ${ }^{57}$ Nevertheless Butler articulates fundamental connection or "interdependence" as an assumed conundrum, rather than as something for which there are alternatives for which it might be necessary to argue. How is it that we are not the same, amorphous body? What are the implications of this for a political life that is more than human?

\section{"The Body" in Butler}

Butler says that "the body has its invariably public dimension." 58 To become a body is to be available to the sensations of others that I am not. And yet 
Butler's homogenizing language here of "the body," which continues into Notes toward a Performative Theory of Assembly, contests the very point that she is making: bodies have this invariably public dimension, this aspect of themselves which is not themselves. ${ }^{59}$ They are seen differently, not because bodies are different in some empirical way, in a way that is verifiable by simple observation. For Butler, there is no simple context-free observation. I cannot survey us from above and report on how we differ in a neutral way. What it is to be a body is to be matter which is not generic or neutral, to be part of a more-than-human world that has its own power distinct from the meanings others try to impose on it or directions others try to give it. There is no "the body" in this sense. The phrase itself suggests something generic. And so bodies do not have inherent meanings, but they are also not carbon copies of each other. My living body does play its own part even as it is what gets interpreted by others externally in ways that will not necessarily correspond to my own life.

Compare this understanding of bodies to that of Michael Hames-Garcia, in an essay entitled "How Real Is Race?"60 There Hames-Garcia argues that a body is "something more than an inert passive object on which ideology inscribes meaning, but rather it is an agential reality with its own causal role in making meaning." ${ }^{\prime \prime 1}$ That in the United States the "one drop rule" operates while in Brazil two siblings with very different pigmentation might be considered to be of different races "does not mean that race does not exist. Rather such differences indicate that the social phenomenon of race emerges differently because of intra-actions among history, economics, law, and human bodily differences in contemporary U.S. and Brazilian societies." HamesGarcia's point is that race is real in the sense that social and political life is also bodily life. To distinguish the political from the bodily, Hames-Garcia rightly suggests, denies this power of a body in politics. He is clearly not interested in reinvigorating scientific racism, but rather he is concerned with the fact that denials of the "reality" of race, and exhortations that inherently meaningless bodily variation is simply not there, have often masked attitudes that those inherently meaningless bodily variations ought not to exist. The vilification of certain bodies in the form of racism can also take the form of a desire for absolute ecological-political homogenization. The insistence that race is not real has certainly not made much of a mark on racially-organized societies, precisely because this claim has been made in the name of a homogenization consistent with racism rather than in the name of undermining racism. In making this point Hames-Garcia writes, "Bodies do not have inherent meanings. Yet, given the physical properties of bodies and the historical sediment of their intra-actions with ideologies and politico-economic practices, one cannot attach just any meaning to any body." 62 
Hames-Garcia is right to suggest that we have to begin to think from examples of precarity. However, his language tends toward the empirical, taking "features of bodies" to be merely witnessable in fact. For example, he writes of the "physical properties of bodies," espousing without quite examining a realism that in fact does take properties to be inherent in bodies themselves. If he were instead to attest to properties as contingent relations among bodies collectively becoming, he would be expressing Butlerian precarity: affective meanings are synonymous with relations among multiplicitous bodies, bodies that are not carbon copies of each other. Empirical or "phenotypical distinctions" are on Butler's view an attempt to skip over the question of how multiplicity attends ecological-political life. ${ }^{63}$ In Butler's view we can't take the meanings - whiteness, for example - that bodies have to be "physical properties." Where does the quality of pigmentation that counts in a specific culture as white stop and the meanings of "whiteness" in that culture begin? Moreover, in many cultures what counts as white skin alone does not necessarily make one a white person. A larger morphology (for Butler it is "the human"64) is involved in the isolation and designation of what can come to seem a merely physical property. In fact it's not clear whether for Butler there is no such thing as a physical property, or whether it is simply too dangerous to try to articulate what might count as a physical property in scientific terminology. At any rate we must explore the modes of relationality that are behind any given candidate for a "physical property."

My suggestion has been that though Butler uses the phrase "the body," her work constantly undermines this phrase. Each life is composed of other distinct and yet mutually dependent lives. I inhabit the earth with others, who I am not. These are perspectives I cannot share, and they are also bodies that I cannot be. Butler further develops this understanding of precarity in relation to Hannah Arendt's notion of plurality. Precarity is now linked to an ecology of existence: to be alive is "already to be connected with what is living not only beyond myself, but beyond my humanness, and no self and no human can live without this connection to a biological network of life that exceeds the domain of the human animal." 65 Politics is by definition a plural "set of bodies," 66 and is thus a moment within a larger ecology that is more-thanhuman, on which human life is absolutely dependent. Butler seeks to articulate her own notion of plurality, one which understands "the body" itself as a site of plurality. She describes this as an encounter with Arendt that "draw[s] upon her resources to clarify" her (Butler's) "own position." ${ }^{67}$ This position, which Butler is already articulating in Precarious Life, turns out also to be a critique of Arendt's "anthropocentrism" and "disavowal of dependency." 68

When we deny that we are bodies for each other-non-neutral bodies that have their own powers both as and in spite of conscious efforts-we 
deny the affective ecology that is constantly renewing, subtly altering, and participating in both what and who we are as bodies. The empirical examples of precarity in any given time and place-differential life expectancies, differential probabilities of death or danger in police brutality, differential encounters with lead exposure, differential incarceration rates-are, on Butler's view, what we typically mean when we refer to "difference," what neoliberal invocations of multiculturalism conceive in their deflationary way as empirical "diversity." ${ }^{69}$ Precarity, as the denial of collective responsibility for such relationships thus becomes a "politically induced condition in which certain populations suffer from failing social and economic networks of support and become differentially exposed to injury, violence and death." ${ }^{\prime 70}$ It becomes a differential exposure to state violence, ${ }^{71}$ including more-than-human (weather, climatological, viral) events. ${ }^{72}$ It is in this context that Butler's philosophy goes beyond sexual difference to articulate the politics of precarity. Precarity is a way of thinking about the non-inevitability and yet bodily concerns of myriad people, "women, queers, transgender people, the poor, the differently abled, and the stateless, but also religious and racial minorities: a social and economic condition, but not an identity (indeed, it cuts across these categories and produces potential alliances among those who do not recognize that they belong to one another)."73 In this point, Butler is insisting that "the human" is far from composed of identical bodies. It may be a further, Irigarayan step to affirm that we are not identical as bodies, that bodies do not share the same abilities, modes of movement, morphological latencies, ${ }^{74}$ but it's a step consistent with Butler's interest in plurality and interdependence. These groups overlap, to the point that more people belong to more than one such "group" than not. Such precarities are always, Butler suggests, an "exploitation of" a precarity that attends life. Not only are we constantly interpreting each others' bodies, but also in spite of all of this interpretation you will never capture (and neither will I) what it is to be the body that "I" am. And vice versa. Absolute intimacy and ultimate obscurity: that's precarity. Echoing Irigaray, Butler says that appreciating precarity and addressing the violence of prevailing responses to it will require an "insurrection at the level of ontology." 75 She broadens Irigaray's attention to sexual difference to include a "new bodily ontology, one that implies the rethinking of precariousness, vulnerability, injurability, interdependency, exposure, bodily persistence and desire, work and the claims of language and social belonging." 76 This bodily ontology affirms its part in a "life that exceeds us." 77 Butler writes, "Can this being be extricated from either ecological conditions or political norms? And in as much as such norms saturate the landscapes of ecology, so too do ecological systems make their demand 
upon politics." 78 Butler's claim is that these terms are complicatedly related or "chiastic." 79 Precarity is a way of problematizing any simple distinction between them. Presumptions about what is human which govern political dynamics, have ecological implications, and ecological life is in turn the larger life without which politics is impossible. I would argue that at least from Gender Trouble on, Butler's work has problematized the very idea of the human as such. What happens via the concept of precarity is the explicit insistence that the "derealization" of some in political life is what necessarily "derealizes all other living organisms." 80 In other words, the denial of precarity is a denial of ourselves as living organisms, and this denial will have differential effects on bodies taken to violate norms of "the human," which is itself consistent with the denial of precarity. Thus, Butler's latest work displays an explicit interest in thinking together the philosophical underpinnings of anthropocentrism and precarity.

It is thus not coincidental that on Butler's own account precarity, as she puts it in Precarious Life, cannot be thought without difference. Precarity is a philosophy of difference as something both of earth and thus necessary, but also subject to myriad relations among bodies. Butler's precarity is an elemental morphology which expresses not a universality or a homogeneity but a primary multiplicity: a situation of myself outside of myself whose denial produces hierarchies of precarity. It is an irreducible dispersal so intimate that it seems to be synonymous with becoming both in the sense of temporal alteration and in the sense of a simultaneous variety.

\section{Two Philosophies of Difference}

I have been arguing that what Butler means by precarity is an inflection of an aspect of Luce Irigaray's ethics of sexual difference: for both philosophers, sexual difference is a concept that problematizes the relation of the biological to the cultural, the ecological to the political. And Butler seems in her most recent work to have taken on the ecological dimensions of Irigaray's philosophy of difference, by other means. In Notes, Butler suggests that to think in terms of the plurality of precarity, the inherently public dimension of "the body," is to begin to contemplate the naive realism of the very term "ecology." Irigaray has long made this point, though (1) this aspect of her work has tended to be overshadowed by its strictly "political" implications and (2) Irigaray questions fundamentally any recourse to the generic concept "the body." But precarity, as a resituating of attention to sexual difference among other modes of difference in ecological-political life, represents an expansion beyond sexual difference so that precarity is itself "a site where a question concerning the relation of the biological to the cultural is posed and reposed." 81 
As discussed above, Butler is not willing to make empirical claims regarding the "physical properties" of bodies. It is because of this that she is also wary of affirming a presupposed heterogeneity that might give rise to an affirmation of morphological difference, as Irigaray proposes. And yet I think that such a presupposition of difference is nevertheless at work in the background of Butler's notion of precarity. Otherwise it's difficult to explain how my body is at all "constituted through perspectives it cannot inhabit." 82 If this body that I am is just like you, then why is it so significant that the "perspective" of the other is "always over there" 83 ? Is this "over there" merely spatial? Butler herself seems to be asking such questions in her critiques of Arendt's abodily notion of plurality. ${ }^{84}$ Each body is a "laboring body and a sexual body, as well as a body gendered and racialized in some form [.] Arendt's view clearly meets its limits here." ${ }^{\prime 5}$ In other words, bodies are not neutral with respect to established morphologies, such as whiteness/masculinity/heterosexuality/health/independence, which privilege certain bodies and are predicated upon the disavowal of others. ${ }^{86}$ Bodies have no inherent meanings, but they do have their own qualities, powers ultimately beyond even the understanding of that body, that body as a living self. Each body is a body of a singular materiality, and this I think is precisely where Butler finds the limits of Arendt's philosophy of plurality.

But it is also in this very aspect of Butler's work, her own philosophy of plurality, that a disagreement with Irigaray appears. Whereas Irigaray hopes for new morphologies which can gather certain bodies together in a way that would conflict with Anthropocene morphology, Butler suggests that the claim that we are different as bodies, and not simply different bodies, arises only as a "negotiation that emerges from being a living creature among creatures." ${ }^{87}$ In other words, for Butler, difference of any sort is strictly a relational negotiation among bodies and can find no justification as inherent bodily features. I don't think, as some have suggested, that Butler's philosophy of bodies is one in which bodies are inert or lacking in thingly power. She is simply and consistently committed to the claim that it's not possible to determine "where the biological, the psychic, the discursive, the social begin and end." 88 To rewrite this claim for the purposes of this essay, for Butler it's not possible to determine where the "ecological" stops and the "political" starts. It's not that bodies don't themselves contradict idealized and generic concepts of bodiment for Butler; they do. It's that no human (who is always an interested party to the larger web of understanding) can say how or when this is happening without reference to a body's relationships with others as "living creatures." How is it possible to claim that some specific feature of a human life is due to it alone and its limitedly isolated status as vibrant earth, and not due to its place in relationships of power among bodies as vibrant 
earth struggling to explain themselves to themselves in a collective way? Butler's claim is that any "new norm of description" is itself the product of bodily activity and is in that sense ecological. What is at stake here is not so much or not only the danger of the normalizing of power relations, but a lack of appreciation of the ecological-political power that we have as bodies among ourselves. Butler in her more recent work is quite explicit that human animals have no monopoly on power, and that human politics are not the only politics of earth. But she will not be willing because of this to overlook negotiations currently informed by "the human," albeit as one aspect of a larger tangle of relations. And especially not in the name of a philosophical approach to difference, such as that of Irigaray, which attempts to revise hierarchies and establish or re-establish new modes of "unliveability."

\section{Conclusion: Precarity as Elemental Difference}

Butler here helps us to name what is problematic about Irigaray's philosophy of sexual difference. Whereas many regard Butler as lacking an appreciation of material agency, I think that she in fact offers an alternative philosophy of difference, and one which importantly disagrees with Irigaray about what claims we can make about it. For example, Irigaray writes, "A sexuate living being cannot represent the entire world because it embodies only a part of the world." ${ }^{89}$ This is the beginning of a philosophy of elemental difference. However, in almost the same thought, Irigaray writes that "the particularity of sexuate individuation entails respect for the other part of the individuation of the species, which forms with it the living environment of this species." $" 90$ In making this statement, Irigaray equates difference with sexuation, making it the whole of difference, and not simply one mode of variety among human bodies that they themselves explore and sense. Butler's philosophy of precarity calls attention to the way Irigaray here homogenizes certain bodies as "one part" of a species. Irigaray's is a morphology of bodies that doesn't appreciate itself as morphology, according to how each one as matter is witnessable by others and with respect strictly to the difference that Irigaray deems fundamental.

More can be said about the problems with stopping at sexual difference in the context of the Anthropocene. As Audre Lorde has suggested, allowing sexual difference to stand in for all modes of difference operates as a kind of protection against a more radical sense of the significance of difference as a feature of elemental life. ${ }^{91}$ As Butler concurs, to gather certain bodies as "of the same sex" is to reinforce multifaceted norms of description and never merely to describe. But even if it is impossible to say where biology stops and sociality starts, where ecology stops and politics (as "negotiations" according 
to "the human"92) starts, I think we must affirm difference as something that is more than unjust creation or human animal misunderstanding. Difference is something that bodies do, and which no one species invented. We might share morphologies, but we do not necessarily share the bodies those morphologies disavow or affirm. We, too, however we might come to figure this "we," are the necessarily heterogeneous life which any possible morphology will presuppose. Even if Butler is right to suggest that an affirmation of elemental difference cannot provide or justify statements about how bodies differ, I think it is important to ask why it is so difficult to admit that bodies surprise us, often aspects of our very own selves-bodies. How is it even possible that (so very many) bodies contradict the norms or "shoulds" of a culture? From where does that power come? Is this a "human" power? Is this a power unique to "human" life? Here Irigaray's philosophy of elemental difference can help us to explore how the generic notion of "the human" does work to form differential life courses and to entrench the dangers and injustices of the Anthropocene, effects that cannot be divided into "the environmental" and "the political." Water crises plague cities also beset by police brutality and the inherent violences of incarceration to those incarcerated as well as their familiars. Migrants are incarcerated rather than seen as members of a community, and increasingly privatized incarceration means the denial of food, water, safety, and again does violence to the relationships among familiars. Lisa Guenther has argued that such practices constitute ontological violations, which deny the relational structure of life and which result in what we could call political/ecological harm to singular persons as well as communities and places. ${ }^{93}$ Why, in such an atmosphere of elemental violence, do we continue to speak in terms that presume a generic continuity of sense: the body, the human, the female, the male? Is this a coincidence? I want to suggest that the point is not simply that elemental difference is impossible to articulate without participating in what elemental differences become. It is rather that elemental difference is what constitutes the context of all ecological-political activity. Precarity, in Butler's sense of a "disposition of ourselves outside ourselves" that is not human in the currently a-bodily sense of this word, is a feature of life that comes before all of the unjust denials - making the context either for its denial or affirmation.

Precarity as elemental difference might allow us to think the politicalecological in a way that resists the impositions of neutrality, a thinly veiled commitment to the hierarchizing of bodies and their power, in a-bodily gestures precisely in a time when we should be reconsidering the implications of denials of the current dynamics of interdependence. It is the power of this earth that we are that accounts for a difference we try in vain either to describe or to dis-regard. We need to think of the political as ecological, the ecological 
as political, and the combination of Butler and Irigaray on elemental difference is one possible starting point.

\section{Acknowledgments}

Many thanks to Jane Bennett and to two anonymous reviewers for deeply helpful reflections and questions on an earlier version of this essay.

\section{Declaration of Conflicting Interests}

The author declared no potential conflicts of interest with respect to the research, authorship, and/or publication of this article.

\section{Funding}

The author received no financial support for the research, authorship, and/or publication of this article.

\section{Notes}

1. Judith Butler, Notes toward a Performative Theory of Assembly (Cambridge, MA: Harvard University Press, 2015), 67.

2. Ibid., $43,118,150$.

3. Ibid., 149.

4. Judith Butler, Frames of War: When Is Life Grievable? (New York: Verso, 2009), 52; Butler, Notes toward a Performative Theory of Assembly, 43.

5. In a recent piece, Irigaray refers with hope to a possible "duality of sexuate identities," revealing that though she takes the Western binary gender system to be a disavowal of "the feminine" and thus a system that appreciates only bodies deemed "masculine" and rejects whatever falls outside of this as either animalistic or feminine, she does regard her work as aiming at the cultivation of a duality. In my own view, a philosophy of elemental difference does not necessitate that human life be made to instantiate any two "sexuate identities." An ethics of elemental difference as opposed to one of sexual difference will affirm the necessary plurality of morphologies arising from the necessary heterogeneity of materiality. Luce Irigaray, "Starting from Ourselves as Living Beings," Journal of the British Society for Phenomenology 46, no. 2 (2015): 103.

6. I have recently edited a special issue on reading Irigaray ecologically, Journal of the British Society for Phenomenology 46, no. 2 (2015). See Luce Irigaray's essay "Starting from Ourselves as Living Beings" included in that issue. See also Alison Stone, Luce Irigaray and the Philosophy of Sexual Difference (New York: Cambridge University Press, 2006), especially 88-93; Terri Field "Is the Body Essential for Ecofeminism?," Organization \& Environment 13, no. 1 (2000): 3960; Christopher Cohoon, "The Ecological Irigaray?," in Ecological Theory: New European Approaches, ed. A. Goodbody and K. Rigby (Charlottesville: University 
of Virginia Press, 2011), 206-14; Helen Fielding, "Questioning Nature: Irigaray, Heidegger, and the Potentiality of Matter," Continental Philosophy Review 36 (2003): 1-26; Stacy Keltner, "The Ethics of Air: Technology and the Question of Sexual Difference," Philosophy Today 45 (2001): 75-82; Astrida Neimanis, "Feminist Subjectivity, Watered," Feminist Review 103 (2013): 23-41; Astrida Neimanis, "Thinking with Matter, Rethinking Irigaray: A 'Liquid Ground' for Planetary Feminism," unpublished manuscript courtesy of the author.

7. Karen Barad, Meeting the Universe Halfway: Quantum Physics and the Entanglement of Matter and Meaning (Durham, NC: Duke University Press, 2007), 178. I find Barad's critique of Butler's Bodies That Matter: On the Discursive Limits of "Sex" (New York: Routledge, 1993) to be very compelling, but I want to add that an important site for appreciating the ironic lack of dynamism of matter in that book is in Butler's reading of Irigaray (see page 47). Butler does not appreciate at least in that publication the differentiating dynamism of matter in Irigaray's account. But by the time of "The End of Sexual Difference?" (it was first published in 2001, in the same year that Butler first presented the work that would become "Violence, Mourning, Politics"), Butler's work as well as her reading of Irigaray has subtly altered. In "The End of Sexual Difference?" she writes that sexual difference is the posing of a problem, a "permanent difficulty of determining where the biological, the psychic, the discursive, the social begin and end" (185, but see 178-86). In other words, Butler disputes neither the materiality of difference nor plurality, but she is unwilling to make fundamental statements about what counts as difference. I return to this departure from Irigaray, which is also a crucial reading of Irigaray, in the final section of this essay. Judith Butler, "The End of Sexual Difference?" in Undoing Gender (New York: Routledge, 2004), 174-203. This essay first appears in Elisabeth Bronfen and Misha Kavka, Feminist Consequences: Theory for the New Century (New York: Columbia University Press, 2001), 414-34.

8. And therefore Irigaray's notion of autonomy will be characterized by a certain mode of dependence or belonging. Irigaray and Emily Anne Parker, "Interview: Cultivating a Living Belonging," Journal of the British Society for Phenomenology 46, no. 2 (2015): 110.

9. As Rachel Jones has pointed out, Irigaray herself introduces the term "sexuate difference" in her later writings to make it clear that she is talking about bodily subjectivity, not "sexual orientation." As Jones puts it, "Irigaray's main concern is not with sexual orientation, but with releasing woman from the phallocentric tradition in which all modes of sexuality are defined in relation to one and the same sex." I will stick to the phrase "sexual difference," keeping this very important clarification of what Irigaray means by "sexual" [la différence sexuelle] in mind. Rachel Jones, Irigaray: Towards a Sexuate Philosophy (Malden, MA: Polity Press, 2011), 187.

10. Jane Bennett, Vibrant Matter: A Political Ecology of Things (Durham, NC: Duke University Press, 2010); Rachel Jones, "Vital Matters and Generative Materiality: Between Bennett and Irigaray" 46, no. 2 (2015): 156-72. 
11. Though Butler conceives of her project as making "an ecological supplement to Arendt's anthropocentrism" I will pursue another route toward a philosophy of difference that highlights the identity of the political and the ecological.

12. Simon L. Lewis and Mark A. Maslin, "Defining the Anthropocene," Nature 519 (2015): 171-80.

13. Ibid., 174.

14. Ibid.

15. Luce Irigaray, "Starting from Ourselves as Living Beings," Journal of the British Society for Phenomenology 46, no. 2 (2015): 101.

16. See Irigaray, "Starting from Ourselves" and "Interview: Cultivating a Living Belonging," 114. For other critiques of this term, see Donna Haraway, "Anthropocene, Capitalocene, Plantationocene, Chthulucene: Making Kin," Environmental Humanities 6 (2015): 159-65; Astrida Neimanis, Cecilia Åsberg, and Johan Hedrén, "Four Problems, Four Directions for Environmental Humanities: Toward Critical Posthumanities for the Anthropocene," Ethics and the Environment 20, no. 1 (2015): 67-97; Eileen Crist, "On the Poverty of Our Nomenclature," Environmental Humanities 3 (2013): 129-47; Andreas Malm and Alf Hornborg, "The Geology of Mankind? A Critique of the Anthropocene Narrative," The Anthropocene Review 1, no. 1 (2014): 62-69.

17. As Rachel Jones has explained, the word morphology takes its meaning from the Greek word morphe, meaning shape or structure or sensible configuration. For Plato, matter was by definition formless. Irigaray's interest is at least in part to develop morphology as shape or structure or sensible configuration and not something other than matter. The sense of morphology in Irigaray is then Irigaray's answer to the Platonic hierarchy of active form and passive matter. Matter is indistinguishable from its own "form," but of course matter is not fixed as any one configuration. Jones, Irigaray, 60.

18. Lewis and Maslin, "Defining the Anthropocene," 172.

19. Aimé Césaire, Discourse on Colonialism, trans. Joan Pinkham (New York: Monthly Review Press), 73.

20. In other words, I am linking the work of Butler and Irigaray to an interest in the Anthropocene and to the question of whether the Anthropocene as a morphology can begin to address a problem that it so palpably reflects. See also Malm and Horborg, "The Geology of Mankind? A Critique of the Anthropocene Narrative," 64.

21. Pace Rosalyn Diprose, "Corporeal Interdependence: From Vulnerability to Dwelling in Ethical Community," SubStance 42, no. 3 (2013): 185-204; Bonnie Honig, Antigone, Interrupted (New York: Cambridge University Press, 2013), 50; Ann V. Murphy, Violence and the Philosophical Imaginary (Albany: State University of New York Press, 2012); and Erinn C. Gilson, The Ethics of Vulnerability: A Feminist Analysis of Social Life and Practice (New York: Routledge, 2004), 42-43, 58-59. See also Sina Kramer, "Judith Butlers' 'New Humanism': A Thing or Not a Thing, and So What?" 5, no. 1 (2015): $25-40$. 
22. Judith Butler, Precarious Life: The Powers of Mourning and Violence (New York: Verso, 2004), 27; Butler, Notes toward a Performative Theory of Assembly, 118-19.

23. Butler, "The End of Sexual Difference?," 186.

24. Such an opposition is unfair in my view. Addressing it will not sufficiently reveal the role of racial difference, of ability difference, of linguistic difference in the hierarchization of bodies which are nevertheless not the same, but articulating the conversation between Irigaray and Butler can help to problematize the separation of the ecological from the political.

25. Butler, "The End of Sexual Difference?," 186.

26. Butler, Undoing Gender, 9.

27. Ibid., 192.

28. My emphasis. Butler, Undoing Gender, 186.

29. Luce Irigaray, An Ethics of Sexual Difference, trans. Carolyn Burke and Gillian C. Gill (Ithaca, NY: Cornell University Press, 1993), 6-7.

30. Luce Irigaray, Sexes and Genealogies, trans. Gillian C. Gill (Ithaca, NY: Columbia University Press, 1993), 173.

31. Following Irigaray, I'm trying to steer clear of the hylo-morphic "em-bodiment" in which something (an immaterial soul or character) crosses over into something else (matter or body). We really have no term that would fit here for existing materially, hence the neologism.

32. Ibid., 171.

33. Ibid., 3.

34. Luce Irigaray, "There Can Be No Democracy without a Culture of Difference," in Ecocritical Theory: New European Approaches, ed. Axel Goodbody and Kate Rigby, 194-205 (Charlottesville: University of Virginia Press, 2011), 194.

35. Ibid.

36. Spike Lee, When the Levees Broke: A Requiem in Four Acts, 40 Acres \& a Mule Filmworks, DVD, 2006.

37. Thus, naming this new era the Anthropocene would appear to be tautology.

38. I am certainly not the first to take issue with this host of assumptions. The work here is almost too numerous to list, but for a start: Lynne Huffer, Are the Lips a Grave?, 34-40; Penelope Deutscher, "Conditionalities, Exclusions, Occlusions," and Gayatri Spivak, "Foreward," both in Rewriting Difference: Luce Irigaray and 'The Greeks, 'ed. Elena Tzelepis and Athena Athanasiou (Albany: State University of New York Press, 2010); Shannon Winnubst, Queering Freedom (Bloomington: Indiana University Press, 2006), 104-7; Mary Beth Mader, "All Too Familiar: Luce Irigaray's Recent Thought on Sexuation and Generation," Continental Philosophy Review 36 (2003): 367-90; Penelope Deutscher, "Between East and West and the Politics of 'Cultural Ingénuité,", Theory, Culture \& Society 20, no. 3 (2003): 65-75; Penelope Deutscher, A Politics of Impossible Difference: The Later Work of Luce Irigaray (Ithaca, NY: Cornell University Press, 2002); Cynthia Willett, The Soul of Justice: Social Bonds and Racial Hubris (Ithaca, NY: Cornell University Press, 2001), 148-51. My own emphasis is on the claim that whether sexual difference is understood di-morphically or as uniquely fundamental, both 
miss out on the radicality of what Irigaray herself names difference. She is speaking of a material singularity and an internal non-identity that is not to be understood with reference to any supposedly comparable body.

39. Please see endnote 9 above on the terms sexual and sexuate.

40. It is always tempting to think of morphology as something other than a body, who operates in a conscious way. I think this is due to the influence of hylomorphism. But as I understand her, for Irigaray, morphology is an arrangement of a body - possibly a little conscious, mostly not—which is not distinguishable from that body itself. This arrangement happens in necessary concert with others of all sorts.

41. After all, it is actually a rare person for whom only one of these elements is at issue. In other words what I'm interested in is a theory of "intersectionality" which is elementally leftist, not liberal.

42. Butler, "The End of Sexual Difference?," 197.

43. Sometimes, as in Frames of War, precariousness is Butler's word for the necessity of the involvement of each life in the lives of others, of which precarity, as differential exposure to the dangerous modes of this, is an exploitation (see Butler, Frames of War, 3, 25). But elsewhere Butler uses the terms vulnerability and precarity for both of these as aspects of a larger philosophy of precarity (e.g., see Butler, Notes toward a Performative Theory of Assembly, 67, 96). I will stick to the term precarity, just for ease of articulation.

44. Butler, Frames of War, 76.

45. Butler, Precarious Life, 151.

46. Butler, Frames of War, 100. Luce Irigaray, Thinking the Difference: For a Peaceful Revolution (New York: Routledge, 1994), 3.

47. Butler, Bodies That Matter: On the Discursive Limits of "Sex" (New York: Routledge, 1993), 49.

48. Butler, Frames of War, 2.

49. Butler, Precarious Life, 27.

50. Ibid., 25.

51. Ibid., 24.

52. Mourning conceived in this way resonates with what Brian Massumi calls the "autonomy of affect": affect is autonomous, or rather accounts for whatever we have called autonomy, in that it is not the vitality of any one body, isolated from others. All autonomy, as Massumi understands it, is actually the autonomy that affect is, traveling from "body" to "body." Likewise for Butler, to become a body is to be undone from within, displaced or dispossessed by the vitality of other bodies, accounting in the background for the power of any one person. Mourning is a specific mode of such affect, many connected verbs composing one neat noun: affecting-being-affected-affecting. To mourn is not a goal of politics. Its importance in this essay lies in the fact that it has the capacity to indicate that lives are constituted by other lives. Brian Massumi, Parables for the Virtual: Movement, Affect, Sensation (Durham, NC: Duke University Press, 2002), 35.

53. Ibid.

54. Butler, Notes toward a Performative Theory of Assembly, 97. 
55. Butler, Precarious Life, 27.

56. Ibid., 28; Frames of War, 50.

57. Butler, Frames of War, 54.

58. Butler, Precarious Life, 26.

59. Ibid., 27.

60. Michael Hames-Garcia, "How Real Is Race?" in Material Feminisms, ed. Stacy Alaimo and Susan Hekman (Bloomington: Indiana University Press, 2008).

61. Hames-Garcia, "How Real?," 327.

62. Ibid.

63. For a view comparable to that of Hames-Garcia see Arun Saldanha, "Reontologizing Race: The Machinic Geography of Phenotype," Environment and Planning D: Society and Space 24 (2006): 9-24. It's not that Butler will disagree with attempts to understand the reality of race, it's that she will not be willing to isolate any one body as a phenotype. "Phenotypical difference" is rather a property of a relationship between heterogeneous bodies, human and more-than-human. So whiteness is a thread in a larger pattern of ways a certain body among other bodies is understoodas more or less trustworthy, virginal, or "appropriately" sexual, capable - and the ways the features of a body are understood are not ultimately distinguishable from a body itself. For Butler there is a "permanent difficulty of determining where the biological, the psychic, the discursive, and the social being end" ("The End of Sexual Difference?," 185). In this way her philosophy of difference departs from that of Irigaray. I return to this contrast in the final section of the essay.

64. An alternative view could be the anthropos presupposed by "the Anthropocene."

65. Butler, Notes toward a Performative Theory of Assembly, 43.

66. Ibid., 58 .

67. Ibid., 75 .

68. I do not have time here to explore fully Butler's reasons for turning to Arendt for the notion of plurality that she articulates in Notes. I can only point out the irony of the fact that while Butler discusses Arendt at length, she also very clearly takes her own interest in the materiality of plurality to be at the very least a significant departure from and possibly fundamentally at odds with what she calls Arendt's "disavowal of dependency." Indeed it is Butler herself who notes that for Arendt "the disavowal of dependency becomes the precondition of the autonomous thinking and acting political subject" while starting from the "condition of dependency and the norms that facilitate its disavowal" is Butler's very project (Butler, Notes toward a Performative Theory of Assembly, 206-7). It is partly because of this strangely vacuous relation to Arendt that I find it fruitful to read precarity, especially as bodily plurality, as an opening up of sexual difference, of binarity into multiplicity, for which Butler called in her earlier work on Irigaray. Butler, Notes toward a Performative Theory of Assembly, 113. See also 86-87, 206.

69. Butler, Notes toward a Performative Theory of Assembly, 68. My own note: "diversity" in the Anthropocene is something for which those waging the war on interdependence have unsurprisingly a very limited taste.

70. Butler, Frames of War, 26.

71. Ibid. 
72. For example, she offers "New Orleans during and after Hurricane Katrina" as an illustration of the fact that it is not "illness and natural disasters" that make for a differential distribution of precarity but rather "how natural disasters for certain areas are preventable for some populations and not for others." Butler, Notes toward a Performative Theory of Assembly, 67.

73. Butler, Notes toward a Performative Theory of Assembly, 58.

74. Butler, Precarious Life, 27.

75. Ibid., 33.

76. Butler, Frames of War, 2.

77. Butler, "On this Occasion ...," 13.

78. Ibid.

79. Butler, Notes toward a Performative Theory of Assembly, 180.

80. Butler, "On this Occasion ...," 12.

81. Butler, "The End of Sexual Difference?," 186.

82. Butler, Notes toward a Performative Theory of Assembly, 97.

83. Ibid.

84. Ibid., 86 .

85. Ibid.

86. This is perhaps a way to understand what is so apparently threatening about the transnational Black Lives Matter movement and its elementally pluralizing mode: it represents a morphology in direct conflict not only with morphologies of whiteness but with that of the Anthropocene in which they are central.

87. Butler, Notes toward a Performative Theory of Assembly, 43.

88. Butler, "The End of Sexual Difference?," 185.

89. Irigaray, "Starting from Ourselves as Living Beings," 103.

90. My emphasis. Ibid.

91. See Audre Lorde, "Age, Race, Class and Sex: Women Redefining Difference," in Sister Outsider: Essays and Speeches by Audre Lorde (Freedom, CA: Crossing Press, 1984), 122.

92. Butler, Notes toward a Performative Theory of Assembly, 43.

93. Lisa Guenther, Solitary Confinement: Social Death and Its Afterlives (Minneapolis: University of Minnesota Press, 2013).

\section{Author Biography}

Emily Anne Parker is an Assistant Professor of Philosophy at Towson University. Her area of research is 20th century to contemporary French philosophy, philosophies of nature and body, and philosophies of political difference. She has served as guest editor of a special issue of the Journal of the British Society for Phenomenology on the ecological-political philosophy of Luce Irigaray. She has also published an essay in the Southern Journal of Philosophy on the significance of "singularite" in Simone de Beauvoir's Ethics of Ambiguity, as well as on the mistranslation and therefore disappearance of this term in English translation. In addition to publications appearing as book chapters, other essays appear in Hypatia: A Journal of Feminist Philosophy, philoSOPHIA: A Journal of Continental Feminism, Philosophy Today, and Trans-Humanities. 